\title{
The Effects of Structural Analogues of Amino Acids on Ammonium Assimilation and Acetylene Reduction (Nitrogen Fixation) in Gloeocapsa (Gloeothece) sp. CCAP 1430/3
}

\author{
By JEANETTE H. THOMAS, PHILIP M. MULLINEAUX, \\ ANDREW D. CRONSHAW, ALAN E. CHAPLIN AND \\ JOHN R. GALLON* \\ Department of Biochemistry, University College of Swansea, Singleton Park, \\ Swansea SA2 8PP, U.K.
}

(Received 9 July 1981; revised 10 September 1981)

In Gloeocapsa, $\mathrm{NH}_{4}^{+}$formed by $\mathrm{N}_{2}$ fixation was assimilated by the glutamine synthetaseglutamate synthase pathway. The inhibition of acetylene reduction following addition of $\mathrm{NH}_{4}^{+}$to $\mathrm{N}_{2}$-fixing cultures was not caused by $\mathrm{NH}_{4}^{+}$itself but was, most probably, related to increased intracellular levels of glutamine.

Analogues of several amino acids inhibited acetylene reduction. Apart from glutamine analogues, which interfered with $\mathrm{NH}_{4}^{+}$assimilation, these analogues probably acted by inhibiting nitrogenase synthesis. Certain analogues of tryptophan and phenylalanine, which have been reported to overcome $\mathrm{NH}_{4}^{+}$inhibition of cell differentiation and, possibly, nitrogenase synthesis in heterocystous cyanobacteria growing on combined nitrogen, did not prevent $\mathrm{NH}_{4}^{+}$from inhibiting acetylene reduction in cultures of Gloeocapsa. In contrast, L-methionine-DL-sulphoximine, which similarly counteracts the effect of $\mathrm{NH}_{4}^{+}$on heterocyst differentiation, also prevented $\mathrm{NH}_{4}^{+}$from inhibiting acetylene reduction in Gloeocapsa.

\section{INTRODUCTION}

In $\mathrm{N}_{2}$-fixing cyanobacteria, as in many other organisms, assimilation of $\mathrm{NH}_{4}^{+}$proceeds by the glutamine synthetase (EC 6.3.1.2)-glutamate synthase (EC 1.4.7.1: the cyanobacterial enzyme is ferredoxin-dependent) pathway (see Miflin \& Lea, 1976). Evidence for the operation of this pathway has been provided by enzymological studies (Dharmawardene et al., 1973; Lea \& Miflin, 1975), radioisotopic data (Meeks et al., 1977, 1978) and also by the use of inhibitors of glutamine and glutamate metabolism, such as L-methionineDL-sulphoximine (Stewart \& Rowell, 1975) and azaserine (Meeks et al., 1977). These inhibitors have also proved useful in studying the mechanism whereby exogenously supplied $\mathrm{NH}_{4}^{+}$inhibits nitrogenase (EC 1.18.2.1), the $\mathrm{N}_{2}$-fixing enzyme.

Other inhibitors of amino acid metabolism have also been used to investigate $\mathrm{N}_{2}$ fixation (acetylene reduction) by cyanobacteria. For example, when added to cultures of heterocystous cyanobacteria growing in medium containing combined nitrogen, certain analogues of tryptophan (Bottomley et al., 1980) and phenylalanine (Rogerson, 1979) allowed the differentiation of vegetative cells into heterocysts. Heterocysts are the site of aerobic $\mathrm{N}_{2}$ fixation in these organisms, but there have been conflicting reports about whether, in the presence of these analogues, nitrogenase activity appears along with cell differentiation (Bothe \& Eisbrenner, 1977; Bottomley et al., 1980; Rogerson, 1979). Finally, canavanine, a structural analogue of arginine, has been reported to inhibit nitrogenase synthesis in cultures of Anabaena flos-aquae (Bone, 1972). 
The unicellular cyanobacterium Gloeocapsa (Gloeothece) fixes $\mathrm{N}_{2}$ aerobically even though it does not possess heterocysts. Consequently, Gloeocapsa is a useful organism in which to study the effects of analogues of amino acids on $\mathrm{N}_{2}$ fixation, because these effects cannot be complicated by cell differentiation. Although in Gloeocapsa $\mathrm{NH}_{4}^{+}$is probably assimilated by the glutamine synthetase-glutamate synthase pathway (Gallon et al., 1978; Meeks et al., 1978), there has been no systematic attempt to examine the enzymes of $\mathrm{NH}_{4}^{+}$assimilation in this organism. In this paper, therefore, we report an investigation into the pathways of $\mathrm{NH}_{4}^{+}$assimilation by $\mathrm{N}_{2}$-fixing cultures of Gloeocapsa and also report the effect on acetylene reduction of inhibitors of $\mathrm{NH}_{4}^{+}$assimilation and structural analogues of various amino acids.

\section{METHODS}

Materials. 2-Amino-4-oxo-5-chloropentanoic acid (AOCP) was synthesized from N-carboxybenzoxy-Laspartyl- $\alpha$-benzyl ester (Cambrian Chemicals, Croydon) as described by Khedouri et al. (1966). L-MethionineDL-sulphoximine (MSX) and azaserine were purchased from Calbiochem, and all other chemicals from Sigma.

Growth of cultures. Gloeocapsa sp. CCAP 1430/3 (Culture Centre of Algae and Protozoa, Cambridge) was grown in 151 sterile medium, either free of combined nitrogen (Gallon et al., 1978) or containing 2 mM$\mathrm{NH}_{4} \mathrm{Cl}$ (Mullineaux et al., 1980).

Preparation of extracts of Gloeocapsa. For the assay of all enzymes except nitrogenase, broken-cell suspensions and cell-free extracts of Gloeocapsa were prepared as described by Tözüm \& Gallon (1979).

Enzyme assays. $\mathrm{N}_{2}$ fixation by cultures $\left(10^{5}\right.$ to $10^{6}$ cells $\left.\mathrm{ml}^{-1}\right)$ was measured by the acetylene reduction technique (Tözüm et al., 1977) after $4 \mathrm{~h}$ aerobic incubation under illumination at $2500 \mathrm{~lx}$.

Glutamine synthetase (EC 6.3.1.2) was routinely measured in cell-free extracts by the $\gamma$-glutamyl transferase assay of Woolfolk et al. (1966). The $K_{m}$ of the enzyme for $\mathrm{NH}_{4}^{+}$was measured using the biosynthetic assay of Shapiro \& Stadtman (1970). Glutamate synthase (EC 1.4.7.1) was assayed anaerobically as described by Lea \& Miflin (1975) using broken-cell preparations prepared under $\mathrm{N}_{2}$. The ferredoxin used in this assay was isolated from Gloeocapsa (Gallon et al., 1973). Glutaminase (EC 3.5.1.2) activity was measured as described by Bergmeyer (1974) except that the buffer used was $50 \mathrm{mM}-N$-2-hydroxyethylpiperazine- $N^{\prime}$-2-ethanesulphonic acid (HEPES)/ $\mathrm{NaOH}$, $\mathrm{pH} 7.5$. Alanine dehydrogenase (EC 1.4.1.1), glutamate dehydrogenase (EC 1.4.1.2) and glycine dehydrogenase (EC 1.4.1.10) were assayed by following the $\mathrm{NH}_{4}^{+}$-dependent oxidation of $\mathrm{NAD}(\mathrm{P}) \mathrm{H}$ at $340 \mathrm{~nm}$ in the presence of the appropriate 2-oxo acid (Haystead et al., 1973). Carbamoyl-phosphate synthetase (glutamine-hydrolysing) (EC 6.3.5.5) and carbamoyl-phosphate synthetase $\left(\mathrm{NH}_{4}^{+}\right)$(EC 6.3.4.16) were assayed by measuring the conversion of $\mathrm{Na}_{2}^{14} \mathrm{CO}_{3}[2.5 \mu \mathrm{Ci}(92 \mathrm{kBq}) ; 0.33 \mu \mathrm{mol}]$ to $\left[{ }^{14} \mathrm{C}\right.$ ]hydroxyurea following $10 \mathrm{~min}$ incubation with a broken-cell suspension $(0.5 \mathrm{ml})$ of Gloeocapsa (Levine \& Kretchmer, 1971).

Other assays. Extracellular $\mathrm{NH}_{4}^{+}$was measured by the method of Chaney \& Marbach (1962) using $1 \mathrm{ml}$ medium removed from $5 \mathrm{ml}$ samples of Gloeocapsa (concentrated 10-fold), previously incubated at $25^{\circ} \mathrm{C}$ for $24 \mathrm{~h}$ under illumination at $2500 \mathrm{~lx}$. Incorporation of radioactivity from $\mathrm{Na}_{2}^{14} \mathrm{CO}_{3}$ into glutamate and glutamine was measured, after $4 \mathrm{~h}$ incubation with or without analogues, as described by Gallon et al. (1978). Protein was measured as described by Bailey (1962). Cell numbers were measured in a haemocytometer (Tözüm \& Gallon, 1979).

\section{RESULTS AND DISCUSSION}

The enzymes of $\mathrm{NH}_{4}^{+}$assimilation

Several $\mathrm{NH}_{4}^{+}$-assimilating enzymes were detected in extracts of Gloeocapsa sp. 1430/3 (Table 1), glutamine synthetase being the most active under $\mathrm{N}_{2}$-fixing conditions. With $\mathrm{NH}_{4}^{+}$as substrate, the $K_{\mathrm{m}}$ of this enzyme was considerably lower than that of either alanine dehydrogenase or glutamate dehydrogenase, the next most active enzymes. In $\mathrm{N}_{2}$ fixing cultures, therefore, $\mathrm{NH}_{4}^{+}$is probably assimilated primarily by glutamine synthetase. However, in extracts from cultures growing on $\mathrm{NH}_{4}^{+}$, glutamate dehydrogenase (NADP) was the most active $\mathrm{NH}_{4}^{+}$-assimilating enzyme and may be involved in $\mathrm{NH}_{4}^{+}$assimilation under these conditions.

Under $\mathrm{N}_{2}$-fixing conditions, the amino acid dehydrogenases could be involved in $\mathrm{NH}_{4}^{+}$assimilation, but their low affinity for $\mathrm{NH}_{4}^{+}$suggests that they would be effective only when intracellular $\mathrm{NH}_{4}^{+}$accumulated to a very high level. Both alanine dehydrogenase and 
Table 1. Activities of enzymes associated with $\mathrm{NH}_{4}^{+}$assimilation in Gloeocapsa

\begin{tabular}{|c|c|c|c|}
\hline \multirow[b]{2}{*}{ Enzyme } & \multicolumn{2}{|c|}{$\begin{array}{c}\text { Specific activity } \\
\left.[\text { pkat (mg protein })^{-1}\right]\end{array}$} & \multirow[b]{2}{*}{$\underset{\text { (M) }}{K_{\mathrm{m}} \text { for } \mathrm{NH}_{4}^{+}}$} \\
\hline & $\begin{array}{l}\mathrm{N}_{2} \text {-grown } \\
\text { cultures }\end{array}$ & $\begin{array}{l}\mathrm{NH}_{4}^{+} \text {grown } \\
\text { cultures }\end{array}$ & \\
\hline Glutamine synthetase & 976 & 341 & $4.0 \times 10^{-4}$ \\
\hline Glutamate synthase & 600 & ND & ND \\
\hline $\begin{array}{l}\text { Glutamate } \\
\text { dehydrogenase (NADP) } \\
\text { Alanine }\end{array}$ & 167 & 797 & $4.2 \times 10^{-2}$ \\
\hline $\begin{array}{l}\text { dehydrogenase (NAD) } \\
\text { Glycine }\end{array}$ & 231 & 291 & $6.9 \times 10^{-2}$ \\
\hline $\begin{array}{l}\text { dehydrogenase (NAD) } \\
\text { Carbamoyl-phosphate }\end{array}$ & 5.67 & ND & ND \\
\hline $\begin{array}{l}\text { synthetase (glutamine) } \\
\text { Carbamoyl-phosphate }\end{array}$ & $1 \cdot 35$ & ND & ND \\
\hline synthetase $\left(\mathrm{NH}_{4}^{+}\right)$ & 0.13 & ND & ND \\
\hline
\end{tabular}

glycine dehydrogenase required NAD as cofactor, and may therefore be a single enzyme. On the other hand, glutamate dehydrogenase required NADP and therefore appears to be distinct from the other dehydrogenases. A similar situation exists in extracts of Anabaena cylindrica which were found to contain NAD-dependent alanine and aspartate dehydrogenases, but NADP-dependent glutamate dehydrogenase (Haystead et al., 1973). No aspartate dehydrogenase was found in extracts of Gloeocapsa, though high rates of oxidation of $\mathrm{NADH}$ occurred in the presence of oxaloacetate, whether or not $\mathrm{NH}_{4}^{+}$was also added; this activity was probably the result of NAD-dependent malate dehydrogenase (EC 1.1.1.37).

Extracts of $\mathrm{N}_{2}$-fixing cultures of Gloeocapsa also contained glutamate synthase which, as in other cyanobacteria (Lea \& Miflin, 1975), required reduced ferredoxin as cofactor. The specific activity of this enzyme was slightly lower than that of glutamine synthetase, but this might be a result of the difficulty of maintaining anaerobic conditions during isolation and assay of glutamate synthase. The observed rates of glutamine synthetase and glutamate synthase activity would be sufficient to assimilate $\mathrm{NH}_{4}^{+}$produced by nitrogenase, which had a maximum specific activity (acetylene reduction) of about 300 pkat (mg protein) $)^{-1}$.

Addition of $\mathrm{NH}_{4}^{+}$to $\mathrm{N}_{2}$-fixing cyanobacteria leads to a rapid decrease in nitrogenase activity, and it has been suggested that glutamine synthetase or a product of $\mathrm{NH}_{4}^{+}$assimilation is involved in this effect (see Stewart, 1980). One such product is carbamoyl phosphate, which inhibits nitrogenase when added to cultures of cyanobacteria (Lawrie, 1979) including Gloeocapsa (Gallon et al., 1978; Gallon, 1980). Carbamoyl-phosphate synthetase activity was found in extracts of Gloeocapsa (Table 1). Activity was greater with glutamine, as nitrogen donor than with $\mathrm{NH}_{4}^{+}$, in contrast to the findings of Lawrie (1979) with $A$. cylindrica. Since the glutamine-dependent carbamoyl phosphate synthetase of Escherichia coli was active with both $\mathrm{NH}_{4}^{+}$and glutamine (Trotta et al., 1973), both carbamoyl-phosphate synthetase activities in Gloeocapsa may be due to a single, glutamine-dependent, enzyme. No glutaminase was detected in extracts of Gloeocapsa, so the activity of glutamine-dependent carbamoyl phosphate synthetase was not the result of the combined activities of glutaminase and carbamoyl synthetase $\left(\mathrm{NH}_{4}^{+}\right)$.

\section{Inhibitors of glutamine synthetase}

L-Methionine-DL-sulphoximine (MSX) is reported to inhibit glutamine synthetase irreversibly, probably by attachment to both the glutamate and the $\mathrm{NH}_{4}^{+}$binding sites (Meister, 1968). 5-Hydroxylysine is a reversible inhibitor of glutamine synthetase and 
Table 2. Effect of inhibitors of $\mathrm{NH}_{4}^{+}$assimilation on acetylene reduction by Gloeocapsa

Cells were collected from batch cultures during the late exponential phase of growth (6 to $10 \mathrm{~d}$ after inoculation). They were then incubated aerobically in the light for $4 \mathrm{~h}$ with $5 \mathrm{~mm}$-HEPES/NaOH buffer, $\mathrm{pH} 7.5$, and the compounds indicated. Acetylene was added to $2 \%(\mathrm{v} / \mathrm{v})$ and the rate of acetylene reduction was measured over the following $60 \mathrm{~min}$. The rates of acetylene reduction are typical; the percentages are the means of at least 12 observations.

\begin{tabular}{|c|}
\hline Addition \\
\hline None \\
\hline $\begin{array}{l}2 \mathrm{mM}-\mathrm{MSX} \\
2 \mathrm{mM}-5-\text { Hydroxylysine }\end{array}$ \\
\hline $\begin{array}{l}2 \mathrm{mM}-\mathrm{AOCP} \\
0 \cdot 2 \mathrm{mM}-\mathrm{AOCP} \\
20 \mu \mathrm{M}-\mathrm{AOCP}\end{array}$ \\
\hline $\begin{array}{l}2 \mathrm{mM} \text {-Azaserine } \\
0.2 \mathrm{~mm} \text {-Azaserine }\end{array}$ \\
\hline $\begin{array}{l}2 \text { mM-Albizziine } \\
2 \mathrm{mM}-S \text {-Carbamoyl cysteine } \\
2 \mathrm{mM} \text {-Glutamic acid- } \gamma \text {-hydrazide }\end{array}$ \\
\hline $\begin{array}{l}2 \text { mM-Glutamine } \\
2 \text { mM-Glutamate } \\
2 \text { mM-Methionine }\end{array}$ \\
\hline
\end{tabular}

$\begin{array}{cc}\begin{array}{c}\text { Acetylene reduction } \\ {[\text { pmol min }} \\ \left.\left(10^{6} \text { cells }\right)^{-1}\right]\end{array} & \begin{array}{c}\text { Percentage of } \\ \text { uninhibited } \\ \text { activity }\end{array} \\ 24 \cdot 3 & 100 \\ 16 \cdot 5 & 68 \\ 14 \cdot 9 & 61 \\ 7 \cdot 3 & 30 \\ 11.4 & 47 \\ 16 \cdot 5 & 68 \\ 2 \cdot 8 & 12 \\ 17 \cdot 0 & 70 \\ 2 \cdot 2 & 9 \\ 2.2 & 9 \\ 73 \cdot 3 & 301 \\ 14.9 & 61 \\ 20.2 & 83 \\ 19.7 & 81\end{array}$

shows kinetics of competitive inhibition (Rabinowitz et al., 1957; Stewart, 1980). Both 2 mM-MSX and 2 mM-5-hydroxylysine inhibited glutamine synthetase by $95 \%$ in extracts of Gloeocapsa. $\mathrm{N}_{2}$-fixing cultures excreted $\mathrm{NH}_{4}^{+}$when incubated with 2 mM-MSX [12.5 pmol $\left.\min ^{-1}\left(10^{6} \text { cells }\right)^{-1}\right]$ or $2 \mathrm{mM}-5$-hydroxylysine $\left[4.16 \mathrm{pmol} \mathrm{min}^{-1}\left(10^{6} \text { cells }\right)^{-1}\right]$. This suggests that glutamine synthetase catalyses the initial step of $\mathrm{NH}_{4}^{+}$assimilation in Gloeocapsa and is further evidence for the operation of the glutamine synthetase-glutamate synthase pathway under $\mathrm{N}_{2}$-fixing conditions.

Acetylene reduction was slightly inhibited by 2 mM-MSX or $2 \mathrm{~mm}-5$-hydroxylysine (Table 2). It is not clear whether simultaneous addition of $2 \mathrm{mM}$-glutamine prevented these inhibitions, because glutamine itself inhibited acetylene reduction (Table 2). Inhibition of acetylene reduction by $2 \mathrm{mM}-\mathrm{MSX}$ was prevented by addition of $2 \mathrm{~mm}$-methionine. Incubation for $4 \mathrm{~h}$ with $2 \mathrm{mM}-\mathrm{NH}_{4} \mathrm{Cl}$ markedly inhibited acetylene reduction, but addition of $2 \mathrm{mM}$-MSX or $2 \mathrm{mM}-5$-hydroxylysine greatly decreased the effect of $\mathrm{NH}_{4}^{+}$(Table 3 ). Indeed, if allowance is made for the inhibitory effects of MSX and 5-hydroxylysine themselves (Table 2 ), these compounds almost completely prevented $\mathrm{NH}_{4}^{+}$from inhibiting acetylene reduction.

Glutamine synthetase in cultures of other cyanobacteria was inhibited by MSX at concentrations much lower than $2 \mathrm{~mm}$ (Stewart \& Rowell, 1975; Meeks et al., 1978). However, in Gloeocapsa, $20 \mu \mathrm{M}$ - or $0.2 \mathrm{~mm}$-MSX failed to prevent $\mathrm{NH}_{4}^{+}$from inhibiting acetylene reduction, probably because MSX may be poorly assimilated by Gloeocapsa. This view is supported by the observation that simultaneous addition of either 2 mM-glutamine or $2 \mathrm{~mm}$ methionine markedly lowered the effect of MSX in preventing inhibition by $\mathrm{NH}_{4}^{+}$(Table 3), probably by interfering with the uptake of MSX (Meins \& Abrams, 1972).

That inhibitors of glutamine synthetase prevented $\mathrm{NH}_{4}^{+}$from inhibiting acetylene reduction in Gloeocapsa suggests that $\mathrm{NH}_{4}^{+}$itself was not the inhibitor and that a product of $\mathrm{NH}_{4}^{+}$ assimilation may have been involved. Addition of glutamine, itself an early product of $\mathrm{NH}_{4}^{+}$ assimilation, only slightly inhibited acetylene reduction (Table 2) but glutamine may not be readily assimilated by Gloeocapsa. Alternatively, carbamoyl phosphate, formed from glutamine, could be the inhibitor (Gallon, 1980). 
Table 3. Amino acid analogues and the effect of $\mathrm{NH}_{4}^{+}$on acetylene reduction by Gloeocapsa

The assays were done as described for Table 2 . The rates of acetylene reduction are typical; the percentages are the means of at least 12 observations. The figures in parentheses show these percentages after correction for the effect of the analogue itself (see Table 2).

\begin{tabular}{|c|c|c|}
\hline Addition* & $\begin{array}{l}\text { Acetylene reduction } \\
{\left[\text { pmol } \min ^{-1}\right.} \\
\left.\left(10^{6} \text { cells }\right)^{-1}\right]\end{array}$ & $\begin{array}{l}\text { Percentage of } \\
\text { uninhibited } \\
\text { activity }\end{array}$ \\
\hline $\begin{array}{l}\text { None } \\
2 \mathrm{mM}_{\mathrm{M}}-\mathrm{NH}_{4} \mathrm{Cl}\end{array}$ & $\begin{array}{r}17.6 \\
3.9\end{array}$ & $\begin{array}{r}100 \\
22\end{array}$ \\
\hline $\begin{array}{l}2 \mathrm{~mm}^{-} \mathrm{NH}_{4} \mathrm{Cl}+2 \mathrm{~mm}-\mathrm{MSX} \\
2 \mathrm{~mm}-\mathrm{NH}_{4} \mathrm{Cl}+2 \mathrm{~mm}-\mathrm{MSX}+\end{array}$ & $9 \cdot 7$ & $55(81)$ \\
\hline $\begin{array}{l}2 \mathrm{mM} \text {-glutamine } \\
2 \mathrm{~mm}-\mathrm{NH} \mathrm{H}_{4} \mathrm{Cl}+2 \mathrm{~mm}-\mathrm{MSX}+ \\
2 \mathrm{~mm}-\mathrm{methionine}^{-}\end{array}$ & $5 \cdot 1$ & 29 \\
\hline 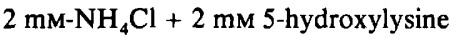 & 9.7 & $55(90)$ \\
\hline 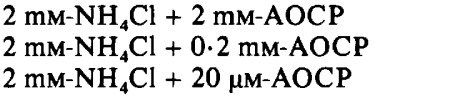 & $\begin{array}{l}2 \cdot 6 \\
4 \cdot 4 \\
5 \cdot 3\end{array}$ & $\begin{array}{l}15(50) \\
25(53) \\
30(44)\end{array}$ \\
\hline $2 \mathrm{mM}^{-} \mathrm{NH}_{4} \mathrm{Cl}+0.2 \mathrm{~mm}$-azaserine & 0.9 & $5(7)$ \\
\hline
\end{tabular}

* The following additions were without effect, at $2 \mathrm{~mm}$, on the inhibition of acetylene reduction by $\mathrm{NH}_{4}^{+}$: 7-azatryptophan, 4-fluorotryptophan, 5-methyltryptophan, canavanine, azetidine-2-carboxylate, 4-fluorophenylalanine and $\beta$-2-thienylalanine.

\section{Analogues of glutamine}

Azaserine and albizziine have both been reported to inhibit glutamate synthase, the second enzyme in the pathway of $\mathrm{NH}_{4}^{+}$assimilation (Lea \& Norris, 1976; Miflin \& Lea, 1976). Azaserine $(2 \mathrm{mM})$ completely inhibited glutamate synthase in extracts and, when added to cultures incubated with $\mathrm{Na}_{2}^{14} \mathrm{CO}_{3}$, caused an accumulation of $\left[{ }^{14} \mathrm{C}\right]$ glutamine [from 16 to $\left.207 \mathrm{~Bq}\left(10^{6} \text { cells }\right)^{-1}\right]$ at the expense of $\left[{ }^{14} \mathrm{C}\right]$ glutamate [which decreased from 176 to $7 \mathrm{~Bq}$ $\left(10^{6} \text { cells }\right)^{-1}$. This is consistent with the operation of the glutamine synthetase-glutamate synthase pathway in Gloeocapsa.

Although azaserine, albizziine and $S$-carbamoyl cysteine are analogues of glutamine, they neither significantly inhibited glutamine synthetase in vitro, nor caused excretion of $\mathrm{NH}_{4}^{+}$when added to a $\mathrm{N}_{2}$-fixing culture. At $2 \mathrm{mM}$, azaserine, albizziine or $S$-carbamoyl cysteine severely inhibited acetylene reduction by cultures of Gloeocapsa (Table 2). Although $0.2 \mathrm{mM}$-azaserine was less inhibitory (Table 2), it exacerbated the effect of added $\mathrm{NH}_{4}^{+}$ (Table 3). Addition of $2 \mathrm{~mm}$-glutamine, simultaneously with analogue ( $2 \mathrm{~mm})$, had little effect on the inhibition of acetylene reduction, nor was the effect of azaserine prevented by addition of 2 mM-glutamate (Table 4). This suggests that inhibition of glutamate synthase probably affects acetylene reduction by causing an increased intracellular concentration of glutamine (or related product), rather than by depleting intracellular glutamate. If this is so, then it can be predicted that addition of MSX, which would abolish accumulation of glutamine, should prevent azaserine from inhibiting acetylene reduction. Simultaneous addition of 2 mM-MSX with 2 mM-azaserine caused less inhibition of acetylene reduction than that caused by azaserine alone (Table 4), so the effect of azaserine, and, probably, $\mathrm{NH}_{4}^{+}$, on acetylene reduction by Gloeocapsa is related to an increase in the intracellular concentration of glutamine or of a related metabolite such as carbamoyl phosphate.

Unlike azaserine, 2-amino-4-oxo-5-chloropentanoic acid (AOCP) is an inhibitor of glutamine-dependent carbamoyl phosphate synthetase (Khedouri et al., 1966). Because it is an analogue of glutamine, AOCP probably inhibits glutamate synthase, but whilst addition of azaserine might result in an increased intracellular concentration of both glutamine and carbamoyl phosphate, AOCP would not allow carbamoyl phosphate to accumulate. Like 


\title{
Table 4. Effects of glutamine and glutamate on the inhibition of acetylene reduction by analogues of glutamine
}

\begin{abstract}
The assays were done as described for Table 2. The rates of acetylene reduction are typical; the percentages are the means of at least 12 observations. The figures in parentheses show these percentages after correction for the effect of the second addition (see Table 2).
\end{abstract}

\begin{tabular}{|c|c|c|}
\hline Addition & $\begin{array}{l}\text { Acetylene reduction } \\
\text { [pmol } \mathrm{min}^{-1} \\
\left.\left(10^{6} \text { cells }\right)^{-1}\right]\end{array}$ & $\begin{array}{l}\text { Percentage of } \\
\text { uninhibited } \\
\text { activity }\end{array}$ \\
\hline None & $22 \cdot 2$ & 100 \\
\hline $\begin{array}{l}2 \text { mM-Azaserine } \\
2 \text { mM-Azaserine }+2 \text { mM-glutamine } \\
2 \text { mM-Azaserine }+2 \text { mM-glutamate } \\
2 \text { mM-Azaserine }+2 \mathrm{mM} \text {-MSX }\end{array}$ & $\begin{array}{r}2 \cdot 4 \\
3 \cdot 9 \\
3 \cdot 1 \\
10 \cdot 9\end{array}$ & $\begin{array}{l}11 \\
18(29) \\
14(17) \\
49(72)\end{array}$ \\
\hline $\begin{array}{l}2 \mathrm{~mm} \text {-Albizziine } \\
2 \mathrm{~mm} \text {-Albizziine }+2 \mathrm{~mm} \text {-glutamine }\end{array}$ & $\begin{array}{l}2 \cdot 0 \\
2 \cdot 2\end{array}$ & $\begin{array}{l}9 \\
10(16)\end{array}$ \\
\hline $\begin{array}{l}2 \mathrm{mM}-S \text {-Carbamoyl cysteine } \\
2 \mathrm{mM}-S \text {-Carbamoyl cysteine }+ \\
2 \mathrm{mM} \text { glutamine }\end{array}$ & $2 \cdot 0$ & $9(16)$ \\
\hline
\end{tabular}

Table 5. Effect of glutamic acid- $\gamma$-hydrazide on acetylene reduction

Where cells were used, they were collected from batch cultures of Gloeocapsa after 6 to $10 \mathrm{~d}$ growth. After incubation for $4 \mathrm{~h}$ in $150 \mathrm{ml}$ Erlenmeyer flasks, the flasks were sealed, acetylene was added, where indicated, to $2 \%(\mathrm{v} / \mathrm{v})$ and, following a further $60 \mathrm{~min}$ incubation, $1 \mathrm{ml}$ of the gas phase was subjected to gas chromatography. The results are the means of five separate observations.

\section{Incubation*}

Gloeocapsa culture $+\mathrm{C}_{2} \mathrm{H}_{2}$

Gloeocapsa culture, no $\mathrm{C}_{2} \mathrm{H}_{2}$

Distilled water $+\mathrm{C}_{2} \mathrm{H}_{2}$

Distilled water, no $\mathrm{C}_{2} \mathrm{H}_{2}$

Gloeocapsa culture +2 mM-glutamic acid- $\mu$-hydrazide $+\mathrm{C}_{2} \mathrm{H}_{2}$

Gloeocapsa culture +2 mM-glutamic

acid- $\gamma$-hydrazide, no $\mathrm{C}_{2} \mathrm{H}_{2}$

Distilled water +2 mM-glutamic

acid- $\gamma$-hydrazide $+\mathrm{C}_{2} \mathrm{H}_{2}$

Distilled water +2 mM-glutamic

acid- $\gamma$-hydrazide, no $\mathrm{C}_{2} \mathrm{H}_{2}$

\section{Ethylene produced \\ $\left(\mathrm{pmol} \mathrm{min}-1 \mathrm{ml}^{-1}\right.$ )}

$8 \cdot 3$

0

0

0

$25 \cdot 0$

$18 \cdot 5$

$1 \cdot 0$

* The volume of culture or distilled water was $50 \mathrm{ml}$ in each case.

azaserine, 2 mM-AOCP did not inhibit glutamine synthetase but markedly inhibited acetylene reduction by cultures of Gloeocapsa (Table 2). This suggests that carbamoyl phosphate is probably not the inhibitor. Furthermore, because azaserine inhibits many metabolic reactions involving glutamine (Buchanan, 1973), the inhibitor may well be glutamine itself. However, this has not been demonstrated. Unlike the other glutamine analogues, AOCP may have reversed, slightly, the effect of $\mathrm{NH}_{4}^{+}$on acetylene reduction by Gloeocapsa (Table 3). However, this effect of AOCP, though consistent, was never great and was only really apparent after correction for the inhibition caused by AOCP itself. Such correction may not be valid, so it would be unwise to attach much significance to these observations.

At $2 \mathrm{~mm}$, glutamic acid- $\gamma$-hydrazide, another glutamine analogue, apparently markedly stimulated acetylene reduction by Gloeocapsa (Table 2). However, detailed examination of the effect of this analogue (Table 5) showed that a compound chromatographically indis- 
Table 6. Effect of several amino acids and their analogues on acetylene reduction by Gloeocapsa

The assays were done as described for Table 2. The rates of acetylene reduction are typical; the percentages are the means of at least 12 observations.

\begin{tabular}{lcc}
\multicolumn{1}{c}{ Addition } & $\begin{array}{c}\text { Acetylene reduction } \\
{\left[\text { pmol min }^{-1}\right.} \\
\left.\left(10^{6} \mathrm{cells}\right)^{-1}\right]\end{array}$ & $\begin{array}{c}\text { Percentage of } \\
\text { uninhibited } \\
\text { activity }\end{array}$ \\
None & 21.5 & 100 \\
2 mM-Tryptophan & 19.1 & 89 \\
2 mM-7-Azatryptophan & $10 \cdot 3$ & 48 \\
2 mM-4-Fluorotryptophan & $2 \cdot 4$ & 11 \\
2 mM-5-Methyltryptophan & $7 \cdot 5$ & 35 \\
2 mM-Phenylalanine & 18.7 & 87 \\
2 mM-4-Fluorophenylalanine & 7.6 & 35 \\
2 mM- $\beta$-2-Thienylalanine & 1.9 & 9 \\
2 mM-Proline & $21 \cdot 3$ & 99 \\
2 mM-Azetidine-2-carboxylate & 9.5 & 44 \\
2 mM-Arginine & $18 \cdot 1$ & 84 \\
2 mM-Canavanine & $15 \cdot 1$ & 70
\end{tabular}

tinguishable from ethylene was produced when $2 \mathrm{~mm}$-glutamic acid- $\gamma$-hydrazide was incubated, with or without acetylene, in the presence or absence of a culture of Gloeocapsa. Glutamic acid- $\gamma$-hydrazide may catalyse reduction of acetylene to ethylene but may also itself react in aqueous solution to give a compound that behaves like ethylene during gas chromatography. Although the nature of this compound has not been investigated, it may be hydrazine; a similar apparent production of ethylene has been observed with solutions of isonicotinyl hydrazide (J. R. Gallon, unpublished observations). The stimulation of acetylene reduction by glutamic acid- $\gamma$-hydrazide (Table 2) is, therefore, an artefact, and the effect, if any, of this analogue on $\mathrm{N}_{2}$-fixation is not known.

The effects of inhibitors of $\mathrm{NH}_{4}^{+}$assimilation on acetylene reduction support the enzymic data that suggest that fixed $\mathrm{N}_{2}$ is assimilated in Gloeocapsa by the glutamine synthetaseglutamate synthase pathway. Furthermore, they confirm that the inhibitory effect of $\mathrm{NH}_{4}^{+}$ on acetylene reduction, which is exerted through an inhibition of nitrogenase synthesis (Gallon, 1980) is caused not by $\mathrm{NH}_{4}^{+}$but by a product of its assimilation. The nature and mode of action of the inhibitor are not clear, but it may be glutamine rather than carbamoyl phosphate, as previously suggested (Gallon, 1980). In some $\mathrm{N}_{2}$-fixing organisms (see, for example, Stewart, 1980) glutamine synthetase itself may be involved in the inhibition of nitrogenase synthesis, but there is, so far, no evidence for this in Gloeocapsa.

\section{Other analogues}

At $2 \mathrm{~mm}$, analogues of tryptophan, phenylalanine and proline all markedly inhibited acetylene reduction by Gloeocapsa (Table 6). In contrast to the findings of Bone (1972) with A. flos-aquae, $2 \mathrm{~mm}$-canavanine had only a slight effect on acetylene reduction. It is possible that canavanine is not easily assimilated by Gloeocapsa.

None of these analogues prevented $2 \mathrm{mM}^{-} \mathrm{NH}_{4}^{+}$from inhibiting acetylene reduction by Gloeocapsa (Table 3, footnote). 7-Azatryptophan, 4-fluorotryptophan (Bottomley et al., 1980) and $\beta$-2-thienylalanine (Rogerson, 1979) have been reported to overcome the inhibition of heterocyst differentiation in filaments of heterocystous cyanobacteria growing on a source of fixed nitrogen. That none of these analogues prevented $\mathrm{NH}_{4}^{+}$from inhibiting acetylene reduction in Gloeocapsa suggests that their effect on heterocyst differentiation is probably direct and not related to any effect on nitrogenase. In contrast, the effect of MSX, which also prevents combined nitrogen from inhibiting heterocyst differentiation (Stewart \& 
Rowell, 1975), may be related to an effect on nitrogenase, because MSX overcame the $\mathrm{NH}_{4}^{+}$-mediated inhibition of acetylene reduction in Gloeocapsa.

In contrast to the effect of glutamine on its analogues, the inhibition of acetylene reduction by the analogues listed in Table 6 was prevented, either in part (tryptophan, proline) or completely (phenylalanine, arginine), by addition $(2 \mathrm{mM})$ of the appropriate amino acid. These analogues probably exert their effect on acetylene reduction by interfering with the synthesis of proteins, including nitrogenase and, indeed, 7-azatryptophan, 4-fluorophenylalanine or azetidine-2-carboxylate, each at $2 \mathrm{~mm}$, appeared to inhibit nitrogenase synthesis almost completely, as measured in the system described by Gallon (1980). Because synthesis of nitrogenase is essential in Gloeocapsa, in order to balance inactivation of the enzyme by oxygen (Gallon, 1980), interruption of nitrogenase synthesis would, during $4 \mathrm{~h}$ aerobic incubation, result in the marked decrease in nitrogenase activity observed in the presence of these analogues (Table 6).

We thank the Science Research Council for the award of a Research Assistantship to A.D.C. and of a Research Studentship to P.M.M. In addition, the contributions to this work of Mrs E. Jones, Mr R. Roberts and $\mathrm{Mr}$ R. Williams are gratefully acknowledged.

\section{REFERENCES}

Bailey, J. L. (1962). Techniques in Protein Chemistry. Amsterdam: Elsevier.

BERGMEYER, H. U. (1974). Methods of Enzymatic Analysis, 2nd edn. New York: Academic Press.

BonE, D. H. (1972). The influence of canavanine, oxygen and urea on the steady state levels of nitrogenase in Anabaena flos-aquae. Archiv für Mikrobiologie 86, 13-24.

Bothe, H. \& Eisbrenner, G. (1977). Effect of 7azatryptophan on nitrogen fixation and heterocyst formation in the blue-green alga Anabaena cylindrica. Biochemie und Physiologie der Pflanzen 171, 323-332.

Bottomley, P. J., Van BaAlen, C. \& Tabita, F. R. (1980). Heterocyst differentiation and tryptophan metabolism in the cyanobacterium Anabaena sp. CA. Archives of Biochemistry and Biophysics 203, 204-213.

BuChanAN, J. M. (1973). The amidotransferases. Advances in Enzymology 39, 91-183.

Chaney, A. L. \& Marbach, E. P. (1962). Modified reagents for determination of urea and ammonia. Clinical Chemistry 8, 130-132.

Dharmawardene, M. W. N., Haystead, A. \& Stewart, W. D. P. (1973). Glutamine synthetase of the nitrogen-fixing alga Anabaena cylindrica. Archiv für Mikrobiologie 90, 281-295.

GALLON, J. R. (1980). Nitrogen fixation by photoautotrophs. In Nitrogen Fixation, pp. 197-238. Edited by W. D. P. Stewart \& J. R. Gallon. London: Academic Press.

Gallon, J. R., Kurz, W. G. W. \& Larue, T. A. (1973). Isocitrate supported nitrogenase activity in Gloeocapsa sp. LB795. Canadian Journal of Microbiology 19, 461-465.

Gallon, J. R., Ul-Haque, M. I. \& Chaplin, A. E. (1978). Fluoroacetate metabolism in Gloeocapsa sp. LB795 and its relationship to acetylene reduction (nitrogen fixation). Journal of General Microbiology 106, 329-336.

Haystead, A., Dharmawardene, M. W. N. \&
Stewart, W. D. P. (1973). Ammonia assimilation in a nitrogen-fixing blue-green alga. Plant Science Letters 1, 439-445.

Khedouri, E., Anderson, P. M. \& Meister, A. (1966). Selective inhibition of the glutamine binding site of Escherichia coli carbamyl phosphate synthetase by 2-amino-4-oxo-5-chloropentanoic acid. Biochemistry 11, 3552-3557.

LAWRIE, A. C. (1979). Effect of carbamoyl phosphate on nitrogenase in Anabaena cylindrica Lemm. Journal of Bacteriology 139, 115-119.

LEA, P. J. \& MifliN, B. J. (1975). Glutamate synthase in blue-green algae. Biochemical Society Transactions 3, 381-384.

LEA, P. J. \& NorRIS, R. D. (1976). The use of amino acid analogues in studies of plant metabolism. Phytochemistry 15, 585-595.

LeVINE, R. L. \& Kretchmer, N. (1971). Conversion of carbamyl phosphate to hydroxyurea. An assay for carbamyl phosphate synthetase. Analytical Biochemistry 42, 324-337.

Meeks, J. C., WolK, C. P., Thomas, J., Lockau, W., Shaffer, P. W., Austin, S. M., Chien, W.-S. \& GaLONSKY, A. (1977). The pathways of assimilation of ${ }^{13} \mathrm{NH}_{4}^{+}$by the cyanobacterium Anabaena cylindrica. Journal of Biological Chemistry 252, 7894-7900.

Meeks, J. C., Wolk, C. P., LockaU, W., Schilling, N., Shaffer, P. W. \& Chien, W.-S. (1978). Pathways of assimilation of $\left[{ }^{13} \mathrm{~N}\right] \mathrm{N}_{2}$ and ${ }^{13} \mathrm{NH}_{4}^{+}$by cyanobacteria with and without heterocysts. Journal of Bacteriology 134, 125-130.

Meins, F., JR \& Abrams, M. L. (1972). How methionine and glutamine prevent inhibition of growth by methionine sulfoximine. Biochimica et biophysica acta 266, 307-311.

Meister, A. (1968). The specificity of glutamine synthetase and its relationship to substrate conformation at the active site. Advances in Enzymology 31, 183-218.

MifLIN, B. J. \& LEA, P. J. (1976). The pathway of 
nitrogen assimilation in plants. Phytochemistry 15, 873-885.

Mullineaux, P. M., Chaplin, A. E. \& Gallon, J. R. (1980). The effects of a light to dark transition on carbon reserves, nitrogen fixation and ATP concentrations in cultures of Gloeocapsa (Gloeothece) sp. 1430/3. Journal of General Microbiology 120, 227-232.

Rabinowitz, M., Olson, M. E. \& Greenberg, D. M. (1957). $\delta$-Hydroxylysine, an inhibitor of glutamine and protein synthesis by the Ehrlich ascites carcinoma cell. Cancer Research 17, 885-889.

Rogerson, A. C. (1979). Modifiers of heterocyst repression and spacing and formation of heterocysts without nitrogenase in the cyanobacterium Anabaena variabilis. Journal of Bacteriology 140 , 213-219.

Shapiro, B. M. \& Stadtman, E. R. (1970). Glutamine synthetase (sheep brain). Methods in Enzymology 17A, 910-922.

STEWART, W. D. P. (1980). Some aspects of structure and function in $\mathrm{N}_{2}$-fixing cyanobacteria. Annual Review of Microbiology 34, 497-536.

Stewart, W. D. P. \& Rowell, P. (1975). Effects of L-methionine-DL-sulphoximine on the assimilation of newly fixed $\mathrm{NH}_{3}$, acetylene reduction and heterocyst production in Anabaena cylindrica. Biochemical and Biophysical Research Communications 65, 846856.

TözüM, S. R. D. \& Gallon, J. R. (1979). The effects of methyl viologen on Gloeocapsa sp. LB795 and their relationship to the inhibition of acetylene reduction (nitrogen fixation) by oxygen. Journal of General Microbiology 111, 313-326.

Tözüm, S. R. D., Ul-Haque, M. I., Chaplin, A. E. \& Gallon, J. R. (1977). The effect of fluoroacetate on acetylene reduction by Gloeocapsa. Biochemical Society Transactions 5, 1482-1484.

Trotta, P. P., Pinkus, L. M., Wellner, V. P., HAsChemeyer, R. H. \& Meister, A. (1973). Structure-function relationships in glutaminedependent carbamyl phosphate synthetase. In The Enzymes of Glutamine Metabolism, pp. 431-482. Edited by S. Prusiner \& E. R. Stadtman. New York: Academic Press.

Woolfolk, C. A., Shapiro, B. \& Stadtman, E. R. (1966). Regulation of glutamine synthetase. 1. Purification and properties of glutamine synthetase from Escherichia coli. Archives of Biochemistry and Biophysics 116, 177-192. 